Educational Research for Social Change (ERSC)

Volume 7 No. 2, September 2018

pp. 117-131

ersc.nmmu.ac.za

ISSN: 2221-4070

\title{
Using students' experiences of lectures as a lens for learning about teaching pre-service teachers: A methodological approach to transformative practice through self-study ${ }^{1}$
}

\author{
Eunice Nyamupangedengu \\ University of the Witwatersrand \\ eunice.nyamupangedengu@wits.ac.za
}

\section{Caleb Mandikonza}

University of the Witwatersrand

caleb.mandikonza@wits.ac.za

\section{Abstract $^{2}$}

Few higher education institutions have training or induction programmes that prepare academics to teach pre-service teachers. How can academics develop and ascertain teaching practices that are appropriate and effective for teaching pre-service teachers? In this self-study, I used Brookfield's four lenses to inform my teaching. Together with a critical friend, I used the community of practice theory and the metaphors of boundary crossing and boundary objects to interrogate my teaching and students' learning using students' experiences as the stimulus for reflection. Findings from this study revealed that pre-service teachers take on multiple identities of teacher, learner, and university student during teaching and learning activities that influence what they learn. The study showed that the pedagogical choices teacher educators make can hinder meaningful learning if they are not aligned to students' identities. The study also showed that investigating and critically reflecting on students' experiences of lectures can be an effective methodological approach for identifying and understanding effective practices for teaching and preparing pre-service teachers. The article concludes by arguing and advocating for teacher educators, as experts in a community of practice, to decolonise their classrooms by making them safe spaces for critical dialogue that allows students' voices and experiences to be heard. Such a practice has the potential to create a community of practice that is characterised by shared knowledge, values, and standards.

Key words: autobiography, boundary crossing, pre-service teacher identities, self-study, student experiences

Copyright: (C) 2018 Eunice Nyamupangedengu \& Caleb Mandikonza

This is an open access article distributed under the terms of the Creative Commons Attribution Non-Commercial License, which permits unrestricted non-commercial use, distribution, and reproduction in any medium, provided the original author and source are credited.

1 Ethical clearance number: 2012 ECE071.

2 This article draws on Nyamupangedengu's doctoral dissertation, Nyamupangedengu, E. (2016). Teaching genetics to preservice teachers: A teacher educator's approach to transformative practice through self-study (Unpublished doctoral dissertation). University of the Witwatersrand, South Africa. 
Please reference as: Nyamupangedengu, E. \& Mandikonza, C. (2018). Using students' experiences of lectures as a lens for learning about teaching pre-service teachers: A methodological approach to transformative practice through self-study. Educational Research for Social Change, 7(2), 117-131. http://dx.doi.org/10.17159/2221-4070/2018/v7i2a8

\section{Introduction}

The study that is reported in this article is a coauthored self-study. The first person singular is, however, used because the experiences of the first author (Eunice) form the basis of the article. The second author (Caleb) played an important self-study role - that of a critical friend-by helping the first author to step back, reflect, and put into perspective, the issues that were playing out in her teaching practices as gleaned from students' experiences of her lectures.

I am a teacher educator responsible for teaching a biology course, genetics, to pre-service teachers (also referred to as students in this article). As is typical of many teacher education institutions, I did not get any preparatory capacity development to become a teacher educator. I am a trained high school teacher and started my teaching career at high school before I was employed at tertiary level. Teaching at high school seemed easier where my role, which was to make students understand the subject matter, was very clear to me. When I became a teacher educator, I did not make any adjustment to my teaching practices in the light of my new role of a teacher educator. It was my participation as a facilitator at a teachers' workshop three years after becoming a teacher educator that triggered my transformation from a high school teacher to a teacher educator functionary. I give an account of this workshop in some detail below because it was my experiences from this workshop that became a motivation for this study.

Three years after becoming a teacher educator, I was invited to facilitate at a workshop on how to teach genetics to subject advisors ${ }^{3}$ for life sciences. I was invited in my capacity as the teacher educator responsible for teaching genetics to pre-service teachers. Genetics is one of the topics considered difficult by teachers and learners in schools. At the workshop, my facilitation focused on the difficulties and misconceptions associated with the teaching and learning of genetics, and how teachers can deal with these misconceptions and difficulties in their teaching. Teachers' evaluations of the workshop were not only positive but also indicated that the session on what makes genetics difficult to learn and how to deal with those difficulties was a highlight of the workshop. When I reflected on the evaluations, I realised that my focus at the workshop was different to my focus when teaching genetics to pre-service teachers back at university. At university, in my teaching of the genetics course, I was focusing on content only with nothing about pedagogy for successful teaching and learning of genetics (see Nyamupangedengu, 2016 for the full autobiography). It dawned on me then that I was no longer a teacher teaching high school learners but a teacher educator teaching prospective teachers and, therefore, I needed to develop new knowledge and skills. The workshop experience stifled and undermined my confidence as a teacher educator. I started to question my own assumptions of what good teaching is when it comes to teaching a content course to pre-service teachers. After reflecting on my practice-focused autobiography, I carried out a self-study during which I investigated students' experiences of my lectures with the aim of learning how best to teach them. In this article, I report on the insights that I got from this investigation of students' experiences. The key questions that guided this study were:

- How do pre-service teachers learn?

\footnotetext{
${ }^{3} \mathrm{~A}$ subject advisor is an educator who is a specialist in a particular subject, in this case life sciences, who then oversees the teaching of that subject in a school district.
} 
- In what ways can reflective engagement with students' experiences inform my teaching?

\section{Literature Review and Theoretical Framework for the Study}

As can be seen in the above description of my experiences, it was my reflections on teachers' experiences of the workshop that became a catalyst for the transformation of my practice towards better learning experiences of pre-service teachers. In this study, therefore, I sought out and reflectively engaged with students' experiences of my teaching so as to learn about teaching them and about their learning with the ultimate desire of developing capabilities in them for teaching in their own classrooms (Sen, 1999). Engaging with the experiences and feedback from students is an approach that faculties can use to improve their teaching because these may reveal teaching practices that can be adjusted or harnessed to promote student access to knowledge and their success (Brookfield, 1995). In this study, I employed Brookfield's four lenses for becoming a critically reflective practitioner to design and carry out this research. Together with my critical friend, we then used the community of practice theory by Lave and Wenger (1991), and the metaphors of boundary crossing and boundary objects by Akkerman and Bakker (2011), as lenses for interrogating my practice from the perspective of the student in the form of students' experiences of my teaching. Our aim was to understand how my teaching was experienced by pre-service teachers, and then to use that understanding to improve our practice. In so doing, we hoped to be transformative activists (Stetsenko, 2008). As transformative activists, while further interrogating my practice we would be demonstrating to pre-service teachers pedagogical practices that are possible for them to enable epistemological access in their schools. I describe Brookfield's four lenses next.

\section{Brookfield's lenses}

The four lenses proposed by Brookfield (1995) for becoming a critically reflective teacher are autobiography, students' eyes, colleagues' experiences, and theoretical literature. According to Brookfield, these lenses correlate with processes of self-reflection, student feedback, peer assessment, and engagements with scholarly literature, respectively. Autobiography is a description of one's life experiences, including one's history and culture, one's actions, one's ideas, the texts one has read, the experiences one has had, and the people one has known (Pinnegar \& Hamilton, 2009). According to Coia and Taylor (2009, p. 5), assessing one's autobiography enables one to reflect "on the past from the perspective of the present where one achieves understanding that will hopefully lead to a better future." In the present study, I undertook a process of self-reflection using the practice-focused autobiographical account of myself (Nyamupangedengu, 2016) mentioned earlier in this paper. Reflecting on the autobiography provided us with a base that became the springboard for looking into and describing my practice while relating it to the intended matter of concern, especially our quest for transformative praxis in pedagogy (Ponte \& Smit, 2013). The notion of practice in this study is understood in the context of doings, sayings, and relatings as expressed by Kemmis et al. (2014).

Students' eyes are the second lens (Brookfield, 1995). This lens covers students' experiences of one's teaching because they tend to make observations of a teacher educator's practice at the same time they are learning concepts and practices (Lortie, 1975). These experiences can be captured through students' feedback in the form of evaluations, assessment answers and results, student journals, and student interview responses. The purpose of finding out and reflecting on students' experiences of my teaching was to understand, from their perspective, those aspects of my teaching that have potential to influence their learning. We also envisaged that students' experiences would create a platform for reflexivity that could lead to the identification of teaching practices that they value and that have potential for emancipatory pedagogical outcomes. 
The third of Brookfield's lenses is colleagues' experiences. Colleagues, especially experienced colleagues, are a rich source of teaching ideas (Nyamupangedengu, 2016 ). When preparing for genetics lectures, I sought colleagues' ideas on pedagogical approaches that can interrogate and trouble current pedagogical practices in preference for more humanising pedagogies and epistemologies (Mandikonza \& Lotz-Sistika, 2016). Ideas from colleagues fed into the teaching preparations.

The last of Brookfield's lens is theoretical literature. Theoretical literature is a rich source of teaching ideas and good teaching habits (van der Vleuten \& Driessen, 2014). As indicated by van der Vleuten and Driessen (2014), evidence of best teaching practices can be found in the educational research literature. In addition, the interactive nature of self-study (see the research design section for details) also entails interaction with the literature (LaBoskey, 2004). In the current study, we read extensively, literature on pedagogical practices to gain knowledge of teaching in general and of teaching genetics in particular. This knowledge is becoming a germ cell for what Engeström and Sannino (2010) described as agency for transformation of pedagogical practice and curriculum transformation. To this end, my quest for transforming my teacher educator practice through reflexive praxis has become our change project (Mandikonza \& Lotz-Sistika, 2016).

\section{Pre-service teacher preparation as a community of practice}

In this study, we considered pre-service teacher preparation as developing a community of practice (CoP) where learning is situated and teaching is learning in practice (Lave \& Wenger, 1991). According to Lave and Wenger (1991), CoP is defined as a group of people sharing common interests and goals whose aim is to develop knowledge and themselves, both personally and professionally. New members enter a CoP through participation. The new members start as legitimate peripheral participants and gradually move towards the centre as participation continues. Three components typify Lave and Wenger's (1991) CoP, namely, domain, community, and practice. In this case, the domain is teacher education, the community is students, myself, and my colleagues, and practice includes teaching, teaching and learning resources, teaching strategies, and professional standards. Within a domain, the commonly adopted practices lead to the establishment of identities, values, standards, and perspectives that become the basis for action, communication, problem solving, performance, and accountability that members are expected to abide by and uphold as members of the CoP.

The metaphors of boundary crossing and boundary objects (Akkerman \& Bakker, 2011) are closely associated with the notion of communities of practice. Akkerman and Bakker (2011) asserted that boundaries are indispensable in identity development, whereupon in order to join a community or to be knowledgeable, one has to cross a boundary through learning. In this study, we assume that teacher educators and pre-service teachers form a community of practice in teacher education. Teacher educators are the experts and the pre-service teachers are the novices being initiated to the knowledge of teaching in general and of teaching genetics in particular. At first year, the pre-service teachers are legitimate peripheral participants and as they move from first year of their Bachelor of Education programme towards qualification, they hopefully gain capabilities, values, and attitudes that see them cross boundaries from the periphery towards the centre where they are expected to participate fully in the CoP. 


\section{Aim of the Study}

The study that is reported in this paper is a self-study in which I investigated and used students' experiences of my teaching as a lens for critically reflecting on my teaching practices, which had been influenced by a critical reflection on my practice-focused autobiography. The aim of the study was to find out how students learn and to identify teaching practices that can be harnessed or strengthened to improve my teaching. Teacher educator practices are likely to be matters of pre-service teachers' concern as future teachers given that the practices have potential to influence their agency to be better teachers (Archer, 1995). To this end, this exploration that has the potential to contribute to the transformation of teacher educator practices in the teaching and learning of pre-service teachers has further possible implications on the way those pre-service teachers would dispose themselves as better and more effective teachers in schools. This becomes particularly important in some South African schools where teachers are blamed for not using innovative pedagogies.

\section{Research Design and Methodology}

\section{Self-study as a research methodology}

Self-study is a study of the self by the self. It is research that is carried out by teachers or teacher educators interested in better understanding and developing their knowledge of practice (Berry, 2008). It involves one's personal teaching stories that arise out of one's own challenges, frustrations, and dilemmas (Samaras \& Freese, 2006). Self-studies in teacher education help teacher educators to learn about themselves and to improve their practice. Five principal characteristics typify self-study methodology and are that the work is self-initiated and focused, the work is improvement aimed, interactive, uses multiple, primarily qualitative methods and validity is exemplar based (LaBoskey, 2004). I explain these characteristics below.

Self-initiated and focused means that the teachers or teacher educators are the researchers and the researched (Samaras, 2011). That the work is improvement aimed means that the work of the teacher educators is aimed at improvement not only of themselves but also of their students, their students' students, and their institutions and social contexts (LaBoskey, 2004). Given that in self-study, the researcher and the researched are one and the same, the study is interactive at one or more stages of the process. The interactive nature of self-study describes the monitoring process whereby critical friends, colleagues, and students get involved in the self-study project (Samaras \& Freese, 2006). Critical friends with their alternative views improve the process, and colleagues ask for clarifications and can offer alternatives (Samaras \& Freese, 2006). The interactive nature of self-study also entails interaction with the literature (LaBoskey, 2004). According to LaBoskey (2004, p. 821), the interactive process "guards against the inevitable limitations of individual interpretation so affected by personal history." Self-study methodology uses multiple, primarily qualitative methods for gathering data. The use of multiple methods provides opportunities for the self-study researcher and for others to gain different angles or viewpoints on the educational processes being investigated, thereby providing a more comprehensive view of the process. That validity is exemplar based means that validation is achieved through constructing, testing, sharing, and retesting exemplars of teaching practice (LaBoskey, 2004). Exemplars of practice are concrete documents and examples of practice that are presented as exhibits to allow members of a relevant research community to judge for themselves the trustwothiness and validity of the observations and interpretations. I chose this methodological approach because its characteristic features as described above would allow me as the researcher to make observations of myself, reflect on my background for insights that could be contributing to the current setting, systematically collect data to represent my observations, and then utilise the study to represent for others what I would come to understand about my practice and, ultimately, to perfect and improve its quality. The methodological features of self-study as described above also allowed for 
what Schon (1983) described as reflection-on-action and reflection-in-action, which promote selfimprovement and transformation of practice through reframing of thinking.

\section{Participants}

As is typical of a self-study, I was the main participant. The other participants were the students. My critical friend provided what Mansfield, Loughran, and Kidman (2016) described as alternative perspectives and analytic advantages. Because this study was done with students as participants, ethics clearance was required and was granted by the university. All 91 students who were registered for the Life Sciences III course were invited to participate in the study by explaining to them on the first day of the course that I was doing a self-study, and what self-study is about. I further explained to them what their participation would entail, which was to give me feedback in various ways during and at the end of the course. After explaining how they would participate in the self-study, students were given consent forms to complete. They all consented to taking part in the study by giving me feedback through lecturer evaluations that are administered through university systems. Thirty-three of these students consented to being interviewed. Of these 33 students, 13 were eventually interviewed. These 13 participants were purposefully sampled so that the interviewees could be representative of the diversity of students in the course in terms of gender, race, and ability. Six of them were men and seven were women. There were eight black students, two of mixed race, two Indian and one white student. Students' marks in the course were used to determine their ability levels.

\section{Data collection}

As is required in self-study, I collected multiple forms of data: my practice-focused autobiography, journal entries of insights from my discussions with colleagues and with my critical friend, and interviews. I also used journaling to document the insights from my reflections. Insights from my autobiography informed my planning for teaching and my actual teaching. Discussions with colleagues were crucial to the study in informing and improving my planning and my teaching of the course. Although they played a crucial role in the implementation of this study, the insights from my autobiography and contributions from colleagues are not explicitly dealt with in this article because its focus is on insights that came from my reflections on students' experiences of my teaching and on the teaching practices that generated those experiences. Therefore, the main data source reported on in this article is interviews with pre-service teachers.

\section{The interviews}

I used a semi-structured interview schedule to gather pre-service teachers' experiences of my teaching practices. The interview schedule is shown in Box 1 below.

1. Describe a typical genetics lecture session.

2. Have you encountered formats other than a lecture?

3. What sorts of content and skills have you encountered so far?

4. What messages about teaching and learning did you understand from genetics classes?

5. How would you describe the level of the work you have encountered so far?

6. Can you describe any experiences of new learning on the course so far?

7. To what extent would you say you have enjoyed the course so far?

8. To what extent have you found the course useful so far?

\section{Box 1: The adapted interview schedule}


Although the interview schedule was taken from a running project, I piloted it to ascertain its effectiveness in the context of interviewing the students myself. The results of the pilot interviews showed that it would be better for the interviews to be conducted by someone who was not present in the lectures, so that students would then provide detailed responses. I also opted for focus group interviews that, according to Bogdan and Biklen (2007), can generate a wider range of responses than individual interviews. In addition, group interviews can also bring together people who hold varied opinions or who are "representatives of different collectives" (Cohen, Manion, \& Morrison, 2000, p. 287). In this case, group interviews brought together students who were representative of the diverse groups in my classroom. To circumvent the disadvantages associated with group interviewing such as the need for skilful interviewing and probing, I sought the services of an experienced person. It was also emphasised that 1 ) the interviews were not about personal matters but about my teaching in the genetics course and 2) that the study was not interested in individual students but their experiences and hence their names were not going to be disclosed to the lecturer or in her research write-ups. We were also alert to poor generalisability of findings from cases. However, Danermark, Ekström, Jakobsen, and Karlsson (2002), using a critical realist approach, claimed that it is possible to generalise findings from a case to the level of structures, mechanisms, powers and, tendencies-but not the events. To this end, this study focused on tendencies that I demonstrated as the teacher educator who generated pre-service teachers' experiences.

\section{Data analysis}

Five interviews were conducted with 13 of the students. The interviews were transcribed and then analysed. The analysis involved both inductive and deductive coding. I coded the first transcript, then, asked my critical friend to independently code the same transcript as part of the validation process. After we had coded the transcript independently, we met and discussed our coding and reconciled any differences. The coding of the first transcript generated the codes that I then used to code the rest of the transcripts. Box 2 below uses a student's response to show how the coding process was conducted.

Student: Well after Mrs Nyamupa's lectures I think I now understand what genetics is (knowledge gained). I understand better than high school (outcome of the teaching) because, you know, in high school I had a very very bad life sciences teacher (evaluation of high school teacher). The genetics course was something else.

Especially when it comes to the hybrids, the crossings and stuff (description of content), the teacher used the textbook and then he would read everything from word to word (description of the high school teacher's teaching procedure) and then couldn't even interpret some of the things (evaluation of high school teacher's teaching) so I think Mrs Nyamupa was the best ever, I understood the topic better (evaluation of the lecturer).

\section{Box 1: A student's coded responses}

After coding all the transcripts as shown in Box 2, I extracted all the different codes from the transcripts and listed them. Below, I list five of the 47 codes that I extracted from the transcripts.

- Description of teaching and learning (T/L) aids)

- Description of purpose of T/L aids

- Evaluation of lecturer

- Description of the high school teacher's teaching practices

- Description of identity 
After listing all the codes, I progressively identified ways of grouping them into categories and eventually collapsed and grouped the codes into these three groups:

- Students' descriptions of their identities

- Students' descriptions of my teaching practices

- Students' responses to my teaching practices.

Caleb and I discussed and reflected on students' experiences using the theories of CoP and boundary crossing as a lens. I present the findings next, using the first three categories as subheadings.

\section{Findings: Insights From the Discussion of and Reflections on Students' Experiences}

\section{Students' descriptions of their identities}

The key finding from this study is that students took on multiple identities during the teaching and learning process. Students largely viewed themselves as teachers but also as learners, university students, and as members of a family and of a community. The utterance below by Ephy ${ }^{4}$ shows some of these identities. The utterance also shows that students were sometimes able to take on multiple identities simultaneously, which enabled them to cross boundaries into other spaces. In addition, the utterance shows that the identity lens that the students were taking on at any given time influenced what they experienced in the course and ultimately their learning:

I have found it useful as I know one day that I'll have to teach this (teacher identity), so with the content that she's given us (student identity/gained content knowledge), I feel comfortable in knowing enough so when I enter that classroom and I have to teach it (teacher identity), I know that my content knowledge is sufficient. As well as by doing this course it's also taught me how to differentiate between genetic disorders and we can, if we encounter one of our friends (friend identity) or family members (member of family identity) to have certain genetic disorders, by doing this course we know how to interact and how to treat them and stuff like that, so by that I know as a student (student identity), I'm taking it as I'm learning about this disorder so I can, if I encounter it in real life, I know how to deal with it.

The utterance shows that Ephy took on identities of teacher, student, friend, and family member simultaneously and, as a result, he was able to learn many different things in relation to the content of genetic disorders. Ephy learned the content knowledge of genetic disorders, and how to differentiate between them. He also learned about the social implications of the knowledge of genetic disorders, and how to interact with friends and family members with genetic disorders.

While some students like Ephy could take on multiple identities simultaneously, others could only take one identity at a time then shift from one to another. Shifting identity, instead of taking on the multiple identities simultaneously, impacted learning. Agnes, for example, showed that during a practical activity in which they were building Reebops, ${ }^{5}$ she shifted identity from that of a learner to that of a

\footnotetext{
${ }^{4}$ All student names used are pseudonyms.

${ }^{5}$ Reebops are imaginary organisms made out of marshmallows and other inexpensive materials. Their features are determined by the characteristics encoded in their DNA/chromosomes. The building of Reebops can be used in a genetics class to show students the connection between meiosis, reproduction, and inheritance.
} 
university student and the shifting then impacted the way she viewed the Reebop activity. As a learner, Agnes found value in the Reebop activity:

We were able to visually see ourselves, we were able to create things ourselves, to give everybody an example of what ... like with the Reebop, that of just mixing it up and making something out of something, it just made it easier to understand maybe how it works in the body and so forth.

However, when Agnes took on the identity of a third-year year student, she then viewed the practical activity as inappropriate:

Okay some of the activities, you'd do it and you'd be like, "Okay, we could have just left that little part out," like with the Reebops with the building of the marshmallows and everything, that for me was just a little bit maybe not for the level of the third-year student (identity, university student). It was a good activity, just the concept, but just maybe don't take it as far as having to build the little creature.

Percy on the other hand, by simultaneously taking on two identities of teacher and learner, was able to evaluate the same Reebop activity as appropriate:

Looking at the practical aspects, especially the practical with the Reebop, it gives a different dimension to what can be done in terms of biology (teacher identity). It makes it more fun and entertaining for if you're looking at kids-Grade 9, Grade 10 (learner identity)-it sort of almost personalises the content to a certain extent where they can actually interact with what's happening and with biology it's not always the easiest thing because you can't give them a live animal and watch this thing mate to a certain extent (subject identity), so it's a good representation, it brings the knowledge onto the learners' level.

Putting on a single identity of a third-year student resulted in Agnes disliking the Reebop activity, which she had, with the identity of a learner, found useful. If Agnes had approached the activity with the identity lenses of both a teacher and a learner as Percy did, she could have appreciated the importance of the activity in its entirety. Because she used the identity lens of a third-year student, the activity, at some point, did not seem appropriate.

Agnes's experiences show that she failed to cross the intended boundaries into the teacher community space as a result of taking on the identities of a third-year university student and of a learner only. Percy on the other hand, by simultaneously taking on multiple identities, was able to cross the boundary into the teachers' CoP space. Agnes' negative perspective of the Reebop activity shows that, as teacher educators, we may unknowingly create or maintain boundaries in our classrooms through the kind of activities that we use and the way we use them in our teaching. As recommended by Loughran (2006), it is therefore important for teacher educators, as experts, to make explicit to their students the tacit knowledge underpinning the pedagogical decisions behind their teaching for the benefit of the students like Agnes.

Students' multiple identities also manifested in the descriptions of their experiences that fall under the other categories of my teaching practices and responses to my teaching practices. In the sections below, as I present the insights from these experiences, I continue to highlight how the various identities that students were taking on impacted their experiences of my teaching. 


\section{Students' descriptions of my teaching practices}

Students experienced my pre-lecture, during lecture and post-lecture teaching practices. The prelecture teaching practices are those practices that are done before lectures. Students did not see or observe these practices but inferred them from what they had experienced during lectures. The prelecture teaching practices that the students identified were preparation, planning, and punctuality. An example of an expressed experience that identifies the pre-lecture teaching practices was made by Munya:

I think, also, the key aspect that she displayed was planning. I learned that if you're going to teach learners, and make sure that they understand, you first as a teacher (teacher identity) must first be prepared-fully prepared-and organise each and every thing that you are going to use, so that when you implement whatever plan you have, you cannot be confused and will be able to clarify any misconception and challenges that you're going to encounter.

The utterance above shows that Munya identified himself as a teacher and this enabled him to infer from observing my teaching, the importance of planning and preparing for one's teaching. Using literature to reflect on Munya's utterance, I came to an understanding that the teaching practices of planning and preparing could be taken as boundary objects (Akkerman \& Bakker, 2011) that facilitated Munya's boundary crossing from a student space to a teacher space. In terms of CoP, Caleb had this to say:

Munya's utterance shows that you are the expert guiding the novices who, in this case, are the pre-service teachers. By referring to himself "as a teacher," Munya is already identifying himself as a member of the community and his utterance shows evidence of learning about teaching from your teaching of, and his participation in, the genetics course.

During-lecture teaching practices include the lecturer's conduct (such as a display of enthusiasm and confidence) and pedagogical practices (such as formative assessment activities), the use of teaching and learning (T/L) aids, and the use of a variety of teaching styles. Below is Naison's description of my conduct during lectures, followed by and Placki and Ngoni's descriptions, respectively, of their experiences of my teaching practices:

In terms of teaching I think that she was active, ja, she was so organised, I think that the lesson itself was just flowing and I was impressed by the way she prepared the lessons, the way she delivered the lessons, she was confident, she was .. I I was very fascinated, I was like... here, we kind-of like doing something for the first time since I came to Wits, seen someone delivering a lesson like that.

$J a$, when she was explaining the chromatin network and how it shortens and thickens with the different ropes like a good visual, like you could actually see it happening and picture it in yourself. And then also getting us to view the slides and identify what cells were going under what. Those were good teaching strategies and tools.

For me, like, science is not very creative, if you don't do tutorials, you do practicals or experiments, but then the teaching styles that I learned from her was presenting role playing and, like, interacting children in groups, because in most cases we, in science, children just do work individually - "do this on your own," and that's the way. 
Naison's utterance shows a student identity and how a lecturer's conduct can bring out the affective experiences of excitement in students during lectures. Placki's utterance shows evidence of learner/student identity as well when she explains how she benefitted from the way I had explained chromatin network using the analogy of string. Her ability to notice and remember the teaching strategies that I used and to evaluate them as good shows a manifestation of a teacher identity indicating that the use of the named teaching strategies had acted as boundary objects that facilitated boundary crossing by students. Ngoni also used the teacher identity to describe the teaching styles that she had experienced, and how that identity had impacted her experiences of my teaching. Caleb had this to say:

Placki's ability to remember and to evaluate the teaching practices that she experienced as good teaching strategies and tools, and Ngoni's appreciation of the teaching techniques used, show that just like Munya, they also took on the identity of a teacher and, with that identity, they were able to appreciate the teaching and learning aids and techniques that you used in teaching them-thereby confirming your role as the expert.

\section{Students' responses to my teaching practices}

The teacher identity influence also manifested in students' responses to my teaching, which in a way, were manifestations of what they had learnt. Firstly, students used a teacher identity lens to describe what they thought were the purposes of my teaching practices. Chipo saw my use of $T / L$ aids as a way of showing students, as future teachers, the kind of resources that they can make use of in poorly resourced schools:

I think another thing is we as teachers (teacher identity), we are going to teach at schools which are not equipped with the resources; the resources she used, any teacher can use, anywhere. So I think it kind-of teaches us to kind-of use different variety of resources. For example, she used pictures, a normal picture. Any teacher can get a picture of the different varieties of cow skin. Another thing she used was the flowers, the roses, she brought red roses, yellow roses, white roses, to show us the different variations of roses, colour in roses.

Tendai viewed the purposes of my teaching approaches as a way of exposing them, as future teachers, to ideas of how to teach genetics concepts:

Well, she gave us a lot of ideas about what we could potentially do in a classroom (reference to the classroom shows that Tendai was viewing herself with the identity of a teacher). Like that role play maybe didn't mean a lot to us in terms of learning about genetic counselling, but it gave us an idea about how we can use that topic in a classroom with kids who would appreciate it and would learn from that.

These are only two examples of the many purposes of my teaching practices that the students described using the identity of a teacher. The teacher identity also manifested in students' evaluations of my teaching. Chipo's utterance below shows that she evaluated the teaching strategies that I used in the course, and came to trust that the strategies could also effectively engage her future learners:

I think I'm going to definitely take away the teaching strategies; the strategies that she used, I think, are applicable to me as a teacher (teacher identity). I can walk into a classroom and I think that I can make the learners engage with the knowledge as fully as Mrs Nyamupa did by using her strategies. 
There is also an aspect of confidence in what Chipo said, showing that the experiences that she had had cultivated confidence in her as a future teacher: "I can walk into a classroom and I think that I can make the learners engage with the knowledge." In addition, there is evidence of apprenticeship and boundary crossing given that Chipo learned about the teaching strategies that she can apply to her future teaching through observation of my teaching.

The learner identity helped students to appreciate the activities that I had used to facilitate their learning. Mufaro, for example, expressed the impact of the presentations that they had done during the course:

We did this chart thing whereby each group explained meiosis and stuff. I found that it was very magnificent, especially with varsity, you know with varsity everything is just pushed up to you but I felt with Mrs Nyamupa, she made sure that we really understand what we're talking about.

Caleb and I discussed at length the implications of Mufaro's utterance that "with varsity, everything is just pushed up to you," and came to realise that our teacher education classrooms could be characterised by top-down lecturer pedagogies that leave no room for students' input, hence, the expression "just pushed up to you" and such pedagogies could be creating and maintaining boundaries that are encountered by students.

\section{Discussion}

This study has revealed that pre-service teachers take on multiple identities including those of teacher, learner, and university student as they participate in the teaching and learning activities. These multiple identities impact the learning and the knowledge that students gain from the teaching and learning activities. The study also showed that some pedagogical activities can create boundaries for students who take on a single identity at any given time during the teaching and learning process, which then undermines the intended learning. It is therefore important for us teacher educators to become aware of such activities and to think more deeply about the assumptions inherent in those activities and then be more explicit on the purposes and intentions of the activities if pre-service teachers are to fully benefit from them. Making explicit the purposes and intentions of teaching and learning activities has the potential to promote the taking on of multiple identities, which in turn, can promote boundary crossing. This study has also shown that when boundary crossing into a variety of spaces is promoted, it has the potential to enable the students to understand the intended learning through whatever methods are used for the benefit of their future learners in schools and their families and communities.

The dominance of the teacher identity in students' utterances showed that the teacher education classroom can be regarded as a CoP in which the teacher educator is the expert and the pre-service teachers are apprentices. Positioning teacher educators as experts in a CoP made us realise that our teaching practices should not only help students to understand content but should also model appropriate teaching practices and behaviours. Pre-service teachers as novices learn about teaching not only from what we teach them but, also, by observing our conduct and how we teach them. This implies that teacher educators need to present and conduct themselves in ways that pre-service teachers can emulate and ultimately influence pedagogical transformation in their schools. Demonstrating the importance of professional pedagogical practices like planning, preparing, punctuality, enthusiasm, and confidence are therefore a key responsibility of teacher educators as experts in the CoP. We teacher educators need to understand that the teacher education classrooms are a CoP space which we need to be alert to and to use as a platform for inducting pre-service teachers 
into the teacher professional community; and, one way of achieving that is by embedding the desired teaching practices in everyday teaching and learning activities.

\section{Conclusion and Recommendations}

Insights that emerged from this study show the potential of using students' experiences of our teaching in self-study as a methodological approach for transformative practice in the teacher education arena. I outline the insights as part of the conclusion to this article, and make some recommendations.

Firstly, this study showed that students' experiences can provide a powerful lens for reflecting on our teaching practices, which in this case enabled us to become aware of some of our roles and responsibilities as teacher educators. The study revealed our positioning: experts in a CoP that is made up of us teacher educators and the students who attend our courses. Viewing ourselves as experts in a CoP will enable us to fulfil our major responsibility: initiating and guiding novices who are pre-service teachers into the knowledge domain and practices of teaching. Viewing the teacher education classroom as a CoP space requires that teacher educators make use of teaching and learning activities that pre-service teachers can relate to, and in a way that they can relate to, and whose usefulness in their own future classrooms can easily be recognised.

Secondly, the methodological approaches that make use of students' experiences and have a component of critical reflection such as self-study have the potential to enable teacher educators to identify and apply knowledge of pedagogical practices that are valued and that tend to provide students with capabilities for enhanced classroom practices. This study showed that such methodological approaches have the potential to respond to humanising tendencies of pedagogic practice as evidenced by pre-service teachers who recognised the effectiveness of activities that personalised the content being learned as something that would make understanding of the concepts easier in their own future classrooms. With such methodological approaches, teaching and learning become a social practice that is shared by the educator and students, rather than the top-down and educator-centred pedagogies that are dominant in many teacher education lecture rooms. Such approaches also contribute to decolonising the teaching and learning space, bridging the gap between the educator and the pre-service teacher that is created by abyssal thinking and abyssal practices (de Sousa Santos, 2007). In this regard, using students' experiences to reflect on our teacher educator practices can therefore contribute to transformation of teaching practices and create better learning opportunities for our students at university and for their own learners in schools after qualification.

Lastly, from the discussion with the critical friend that followed the interviews, was is evident that the teacher educator was able to reflexively engage with own practice but in a community that included colleagues and students. The educator engaged in teaching and learning together with the students. The process of teaching and learning, therefore, became a social practice in a community of the educator and learners. Reflections of the educator were no longer done in isolation from the learners but in a classroom social context. In addition, the reflections formed part of the social practice of teaching and learning. Therefore, extending the notion of CoP, the study showed that it is important to work collaboratively, as teacher educators, with critical friends and one's students who become significant others who help make teaching and learning a social practice, rather than an individually located ability.

\section{References}

Akkerman, S. F., \& Bakker, A. (2011). Boundary crossing and boundary objects. Review of Educational Research, 81(2), 132-169. http://doi:10.3102/0034654311404435 
Archer, M. S. (1995). Realist social theory: The morphogenetic approach. Cambridge, UK: Cambridge University Press.

Berry, A. (2008). Tensions in teaching about teaching: Understanding practice as a teacher educator (Vol. 5). Dordrecht, Netherlands: Springer.

Bogdan, R. G., \& Biklen, S. K. (2007). Qualitative research for education: An introduction to theories and methods. Boston, USA: Pearson.

Brookfield, S. (1995). Becoming a critically reflective teacher. San Francisco, USA: Jossey-Bass.

Cohen, L., Manion, L., \& Morrison, K. (2000). Research methods in education. London, UK: RoutledgeFalmer.

Coia, L., \& Taylor, M. (2009). Co/autoethnography: Exploring our teaching selves collaboratively. In D. Tidwell, M. Heston, \& L. Fitzgerald (Eds.), Research methods for the self-study of practice (Vol. 9, pp. 3-16). Dordrecht, Netherlands: Springer.

Danermark, B. Ekström, M., Jakobsen, L., \& Karlsson, J. (2002). Explaining society: Critical realism in the social sciences. London, UK: Routledge.

De Sousa Santos, B. (2007). Beyond abyssal thinking: From global lines to ecologies of knowledges. Review, 30(1), 45-89.

Engeström, Y., \& Sannino, A. (2010). Studies of expansive learning: Foundations, findings and future challenges. Educational Research Review. doi:10.1016/j.edurev.2009.12.002

Kemmis, S., Wilkinson, J., Edwards-Groves, J., Hardy, I., Grootenboer, P., \& Bristol, L. (2014). Changing practices, changing education. London, UK: Springer.

LaBoskey, V. K. (2004). The methodology of self-study and its theoretical underpinnings. In J. Loughran, M. L. Hamilton, V. K. LaBoskey, \& T. Russell (Eds.), International handbook of self-study of teaching and teacher education practices (Vol. 12, pp. 817-870). Dordrecht, Netherlands: Springer.

Lave, J., \& Wenger, E. (1991). Situated learning: Legitimate peripheral participation. Cambridge, UK: Cambridge University Press.

Lortie, D. (1975). School-teacher: A sociological study. Chicago, USA: University of Chicago Press.

Loughran, J. (2006). Developing a pedagogy of teacher education: Understanding teaching and learning about teaching. London, UK: Routledge.

Mandikonza, C., \& Lotz-Sistika, H. (2016). Emergence of environment and sustainability education (ESE) in teacher education contexts in Southern Africa: A common good concern. Educational Research for Social Change (ERSC), 5(1), 107-130.

Mansfield, J., Loughran, J., \& Kidman, G. (2016). Developing knowledge of practice through self-study: Becoming a science teacher educator. In G. A. Buck \& V. L. Akerson (Eds.), Enhancing professional knowledge of pre-service science teacher education by self-study research (pp. 385-405). Basel, Switzerland: Springer.

Nyamupangedengu, E. (2016). Teaching genetics to pre-service teachers: A teacher educator's approach to transformative practice through self-study (Unpublished doctoral dissertation). University of the Witwatersrand, South Africa.

Pinnegar, S., \& Hamilton, M. L. (2009). Self-study of practice as a genre of qualitative research: Theory, methodology and practice (Vol. 8). London, UK: Springer.

Ponte, P., \& Smit, B. (2013). Education for all as praxis: Consequences for the profession. Professional Development in Education, 39(4), 455-469. http://doi:10.1080/19415257.2013.796296 
Samaras, A. P. (2011). Self-study teacher research: Improving your practice through collaborative inquiry. Thousand Oaks, USA: SAGE.

Samaras, A. P., \& Freese, A. (2006). Self-study of teaching practices. New York, USA: Peter Lang.

Schon, D. A. (1983). The reflective practitioner: How professionals think in action. New York, USA: Basic Books.

Sen, A. K. (1999). Development as freedom. Oxford, UK: Oxford University Press.

Stetsenko, A. (2008). From relational ontology to transformative activist stance on development and learning: Expanding Vygotsky's (CHAT) project. Cultural Studies of Science Education, 3, 471-491. http://doi:10.1007/s11422-008-9111-3

Van der Vleuten, C., \& Driessen, E. (2014). What would happen to education if we take education evidence seriously? Perspectives on Medical Education, 3(3), 222-232. 